\title{
WHANAU, WHAKAPAPA AND IDENTITY IN EXPERIENCES OF ORGAN DONATION AND TRANSPLANTATION
}

\author{
Robert Webb \& Rhonda Shaw
}

\begin{abstract}
This article is based upon qualitative interviews with Maori and their whanau, and explores research into the direct experiences and perspectives of Maori on organ or tissue donation and transplantation. The participants in this research reflected upon their experiences with references to understandings of embodiment, the meanings of the gift in donation, identity as Maori, and cultural wellbeing. The research indicates that these experiences were often linked to wider understandings of whanau and whakapapa, rather than just individualistic notions of the body and transplantation as an end point of health care and wellbeing.
\end{abstract}

\section{INTRODUCTION}

Assumptions that Maori do not typically donate organs for transplantation due to cultural and spiritual reasons abound in the New Zealand media. These claims tend to be based on common sense notions of a monolithic Maori world view that does not necessarily reflect empirical evidence. This article introduces research into Maori experiences and perceptions of organ or tissue donation and transplantation. Based upon in-depth interviews with Maori recipients and donors, their whanau and those with direct experience of donation, it explores the transplantation process from the perspective of those who have been associated with giving or receiving organs or tissues.

In this research participants reflected on a range of areas, from understandings of donation, bodily integrity and spirituality, views on care, to the importance of whakapapa and whanau. From the different themes identified in the research literature, the following article examines conceptions around embodiment and transplantation, perceptions of donation and meanings associated with the terminology of the 'gift', understandings of whanau, whakapapa and 
identity, and different understandings around cultural and spiritual wellbeing. The article will explore how some themes illustrate the complexity and diversity of Maori views, showing culturally distinctive experiences for some Maori participants in the research, while also sharing some commonality with the experiences of others in related research.

Studies have been undertaken on the broader topic of Maori and organ or tissue donation. These have tended to focus on views of professionals or the Maori public on donation aspects, rather than the experiences of Maori directly involved in donating or receiving. A recent study by Mauri Ora Associates (2009) for the Ministry of Health, for example, explored the views of health professionals on Maori and Pacific renal patients. The Ministry of Health (2004) also identified views on organ and tissue donation from submissions on the Review of the Regulation of Human Tissue and Tissue-based Therapies. Within the summary, some submissions identified key cultural concerns for Maori. Additionally, Lewis and Pickering (2003) have examined Maori spiritual views in relation to organ donation, noting the importance of these beliefs to understanding Maori views on transplantation. There has also been related but distinct research into the area of Maori attitudes to assisted human reproduction by Glover (2008) and Glover and Rousseau (2007), and Maori views on genetically modified organisms by Roberts (2005) and Roberts and Fairweather (2004). The perspectives of individuals in New Zealand related to organ donation and transplantation has been addressed in previous qualitative research examining the views and experiences of donors and recipients; the views of the medical professionals involved in transplantation, specifically intensivists and donor and recipient coordinators; and in a phenomenological discussion of putative Maori and non-Maori views of organ donation and transplantation (see Shaw, 2008; 2010a; 2010b). In these sociological studies, various aspects of embodiment, ethics and social relationships are explored. The present article contributes to this literature through specifically examining Maori experiences of organ and tissue donation and transplantation.

\section{METHODS}

This article examines research from a qualitative study of Maori experiences and perceptions of tissue or organ donation and transplantation, and is part of a larger study on perceptions of embodiment and ethics in tissue or organ transplantation. The study advertised nationally for participants, and the interviews took place in 2009 to 2010. Participants were self-selected and recruited through snowball sampling, and were from cities and towns around the North Island. Each interview was 60 to 120 minutes long, and was conducted 
either at the home or workplace of the interviewees. The study comprised 16 interviewees; including those who had donated, received or were whanau of those who had given or received organs or tissues. ${ }^{2}$ These have included heart recipients, kidney recipients, a liver recipient, kidney donors and whanau; a Maori donor coordinator; and the whanau of a tissue recipient, and of a tissue donor. Two of the interviews included both the donor and recipient of an organ (kidney). The participants were all employed, or self-employed. There were ten women and six men interviewed. The interviews explored the experiences of donation or transplantation, conceptions of embodiment, and perceptions of the donor system. The interviews were transcribed by a research assistant, and the data was coded and analysed thematically.

In exploring the views and experiences of participants, it should be noted that this article is not intended to provide the 'Maori' view of transplantation. Maori hold diverse beliefs, and as Durie (2008) observes, there is a distinction between a research study that explores experiences from a sample of Maori, and the indigenous Maori world view. The latter, as Durie states, is more likely to come from a panel of experts in a particular area. In this regard, Te Puni Kokiri (1999a; 1999b) has published guidelines for organ transplantation involving Maori. This article, however, does attempt to elucidate the particular understandings and experiences of Maori participants as they relate to tissue or organ donation. These understandings are framed by the themes of embodiment, meanings of the gift, wellbeing, and views on donation and identity, all of which relate directly to research questions underpinning the larger study.

\section{EMBODIMENT}

Research drawing on phenomenological accounts of organ donation with nonMaori emphasises the significance of what we do with and to our bodies for self and identity constitution (e.g., Haddow, 2005; Shaw 2010b). Taking a cue from this work a core aim of the present study was to investigate whether these accounts of embodied subjectivity resonate for Maori in terms of the experience of organ donation and transplantation. To this end interviewees were asked about their understandings of the body generally, and also specifically in relation to transplantation. For participants in this study understandings of embodied subjectivity were sometimes linked to whanau and whakapapa, and to wellbeing, including spiritual and cultural needs, which are discussed in a subsequent section. These aspects of embodiment, that link the individual to the social, the physical to the spiritual, frame attitudes that are said to distinguish Maori from non-Maori conceptions regarding the ethics of organ donation and transplantation (Lewis and Pickering, 2003). 
This holistic view of embodiment is articulated in the following quotation from a participant in this study. When asked if Maori had a specific conception of the body, this interviewee referred to the 'whare tapa wha' health model, and described this model as reflecting a Maori cultural world view on health and organs. They observed that all the elements of this model were important in Maori understandings of health, but felt these were not recognised by other more dominant approaches to health and wellbeing, in psychology for example. As this interviewee put it:

If you have a look at Maori culture, take te whare tapa wha, and look at the four pillars of health and one of those pillars is wairua. Now if I go back to my training, which is in psychology, there isn't necessarily any room given to the notion of wairua or hinengaro and things like that-not in a Maori reference way. So I think there is a difference in the way we think. It's not necessarily about just an organ.

The whare tapa wha model to which this interviewee refers is described by Durie (1985) as representative of a four sided whare that incorporates whanau (family), hinengaro (mind, or thoughts and feelings), tinana (body), and wairua (spirit). The model thus entails a Maori conception of health involving interrelated elements that go beyond just the individual. As Durie states, 'consistent with this style of thinking, health is viewed as an inter-related phenomenon rather than an intra-personal one. Understanding occurs less by division into smaller and smaller parts' (1985:484). This wider conception of health, and how it was related to whanau was evident in other participants' views.

Participants also referred to the importance of whakapapa for Maori in understanding tissue donation. One participant said:

The best way I can put it is that it's a whole whakapapa that sits behind you as a person; that has created you as a person, and not just the whakapapa but the culture, that it's embedded in this world. My feeling is that that contributes to the way we see organ donation and things, even if it's just blood donation I think.

As a concept, whakapapa refers to a range of different aspects that permeate the whole of cultural life. For Metge (1995, p.48), whakapapa literally means 'to place in layers', and can refer to genealogy that provides a link between past generations, to the present and the future. It provides the basis for relationships in whanau with hapu and iwi, and with others. Similarly, Te Rito (2007) observes that whakapapa provides an important foundation for Maori 
social identity, and is strongly linked to turangawaewae. Lewis and Pickering (2003:33) point out that an individual's body can also be conceived of as the physical manifestation of whakapapa. And, as Roberts, Haami and Benton et al. (2004) note, the term can refer to the knowledge and narratives about plants and animals for Maori, and is a construct that shows the relationships between the spiritual and material world.

Several participants conveyed particular donation issues related to whakapapa. A participant who had donated a kidney to a spouse, reflected on the issue of kidney donation from a non-related donor. They saw strength in donating a kidney within the whanau, and remarked that donating a kidney to a spouse helped to strengthen their whakapapa. As they put it, 'Part of us would kind of believe some point along the way that possibly there could be a donor that would come up. And I think if there had have, we probably would have grabbed it anyway. I think that in the end, this solution between us, I think, I think has helped strengthen our whakapapa'.

Another participant, whose whanau had both donated and received tissue, commented that different issues would have to be considered for donors outside the whanau. They said:

But I suppose it's like me, that's my sacred whakapapa, that is not, um, I'm the vessel for that in the present time. And I think it goes beyond the idea of ownership, you know, it's not about that I own my body. So we would have confronted different issues if we had to accept a non-related donor.

For this participant, the body is more than just a physical entity or objectified attribute of the individual's self. They perceive it as a link between past and present generations, with the concept whakapapa explaining its significance. This is why, as Lewis and Pickering (2003:35) observe living donation within a whanau may be considered more acceptable for some Maori when considering the intermingling of whakapapa.

The concept of whanau or family wellbeing also arose in some interviews in relation to the body. A participant, another live kidney donor who had donated to a spouse, felt the boundaries between bodies was linked to their families. They noted:

I can see why it's going to be close family and partner who are going to donate. Not just because of the incentive thing, but, it's almost like 
the boundaries between your body and theirs are much less. So you kind of, I mean you're obviously self-contained but if you're sharing your life, if you're sharing everything else with someone then some of those boundaries are kind of less. It's still some kind of miracle that my kidney's gone from here to there, but it doesn't seem that strange. It seems quite normal to do that. It's not because I think that my body parts are detachable, but because we share our whole lives.

This participant also acknowledged that different emotional issues were at stake in accepting a donation from a deceased donor.

Not only in the giving and receiving of organs, some participants also considered cultural issues around what happened to an organ after the operation. Two heart recipients in this research spoke of taking their removed organs home for burial with whanau. In this regard, the question of embodiment is not simply a factor related to the incorporation of organs from another person but also includes how to deal respectfully with the loss of a precious body part, beyond construal of that body part as 'waste'.

One participant, a live kidney donor, also noted that issues of cultural concern related to what would happen to the donated kidney if the transplant was not successful. They remarked:

Well I think the cultural issues were for me that was the stark differences between responses, the different responses from the families, the, there was certainly some cultural issues at the time of the ... actually I remember at an appointment with [the doctor], actually, where we'd gone through the process and he described what would happen, and it I mean it became clear that the operation was going to be quite major for the donor, because effectively you're taking a well person in to do major surgery on. And, but the only thing I was interested in at that time, wasn't so much that or the details of that, I just wanted to know, or be reassured that actually [...] I wanted to know if it had failed I wanted to know what they were going to do with my kidney. So I wanted some reassurance that that kidney would have come back to us and we would have disposed of it, in a cultural way, not it being drained down the sink at the hospital.

The importance given to burying the organs was thus related to the beliefs and observances around burial of the body for several participants. 
These participants recognised that a cultural concern for Maori was going to the grave with the body intact, phrased as 'going to the grave whole'. In light of this concern, Jennifer Ngahooro (2010), a commentator on organ donation for Maori, has proposed using powhiri as a ceremony for body parts that are donated by Maori. Ngahooro suggests that Maori cultural concerns over being buried whole and intact, might be alleviated by a ceremony that farewells the organs. Additionally, she proposes augmenting this with another ceremony to support the families that receive through donation.

\section{MEANINGS OF GIFT}

As Waldby and Mitchell (2006) point out, discussion about the transfer of organs and body tissues as gifts has been greatly complicated by the introduction of new medical technologies and the movement of tissues across geographical and national boundaries as part of global economies of exchange. Despite these shifts, and criticisms of the notion of the gift by scholars working in this area (see Tutton, 2004; Healy, 2006), gift rhetoric remains prevalent in the New Zealand media and institutional brochures and information leaflets promoting donative acts. Recent research shows that people directly involved in giving and exchanging body tissues often question the salience of the notion to describe their experience (Shaw, 2008; 2010a). Data from interview transcripts in the present study tend to confirm this.

There was a variety of views from interviewees on this subject. One participant felt the term 'gift' did not adequately capture that transplantation was a required medical treatment. They noted that:

gift language takes it away from [the fact that] this is a real medical issue and very real problem for our health system and the people that are affected, and this is the medical treatment that's available. We should try to encourage people to do it and not turn it into some kind of spiritual experience.

By contrast, another participant in this research did agree with the use of the term 'gift', saying, 'Yes, gift fits for me because, and it fits for everybody else because whenever you see things it's gift, gift, donor'. They also stated they did not agree with the clinical term 'organ harvesting. Other participants referred to 'treasure' or 'taonga' as terms that distinguished the importance of the transplant to their lives. One participant remarked:

I would describe it as a gift, but a gift sounds too cheap, I think it 
was more, how can I say, because these people donated their family members' organ ... And I have been fortunate enough to do things beyond my capabilities, beyond my capabilities prior to the operation. I have done things... this heart has allowed me to do things beyond my expectations. So personally I don't consider it as a gift but I consider it as a treasure, because a gift is a little thing, and the heart is by far bigger than a gift.

Such a statement emphasises the magnitude of the gift for this interviewee in contrast to a conception of gifts as fungible, substitutable, and disposable. Further, in making the point that donated organs are gifts of taonga, this interviewee intimates that organ transplantation instantiates social relations precisely because the donative act is invested with the vitality of the donor (see Henare 2007 for a discussion of the meaning of taonga).

One participant agreed with the use of the term ' gift', and invoked an altruistic understanding of the gift process and receiving an organ. They commented:

I was ready to receive if someone was ready to give, no holds barred no conditions nothing. If someone was wanting to give me a liver and says you have to do this you have to do that before I give it to you, I would rather go. But I was also ready to receive in any way, and if I was lucky enough to get one, once it became mine, it would be my liver. It wouldn't be me and the liver, it was part of me. And that's just how I felt, and from day one I sort of treated it as my own liver. And I am really surprised that it was my liver, and it was a gift that was given to me, but it is mine and I wanted to accept it on my terms, and if it wasn't given in the same manner, well then it probably wasn't going to work.

A heart recipient spoke of the donor's heart as being a whangai, a Maori term that refers to fostering or adopting a child. 'Yeah I'll give it back one day when I go again. It's like I consider it to be like a whangai child sort of. I'm whangai or my heart is whangai to me until I go again and give it back', they said.

Another participant spoke of the kidney donation to their spouse, and by contrast, they invoked meanings of exchange and social relations. They referred to this as a 'koha' that was also related to reciprocity, and the wider relationships of whanau over generations. They reflected:

I would feel more comfortable with it being seen as a koha, and a 
koha in terms of its broad sense that comes with a reciprocal arrangement too that deepens the relationship. And it's not just between the two [people involved], you know. It's not, I don't see it, the koha isn't just between the two that was involved in it, it's much wider, it's between our two families and generations too.

This participant's views on reciprocity as a live (emotionally related) donor can be contrasted and distinguished from comments by other participants who received from anonymous donors.

Some participants equally felt the importance and need to demonstrate reciprocity as mentioned above. However, as a whanau member of a recipient commented, the whanau's obligations that s/he perceived for them as Maori receiving organs was difficult when the donor was anonymous. As they elaborated, anonymity in the transplant system itself did not easily allow for whanau acknowledgement or reciprocity. For this reason, they felt the term 'gift' did not capture all the cultural understandings and meanings for them as Maori. They remarked, 'I don't like the connotations of calling it a gift. To me there are some obligations, there are some connotations surrounding obligation in terms of being a recipient and a recipient whanau and calling it a gift'.

They commented further:

In saying that there are some inherent problems with the transplant system as it is, not only for donors but for recipients as well. And some of them are necessary things like the confidentiality around donors and around donor families. It's a must really, if we're looking at ethics it's a must but the emotional part, sometimes you want a face to the name or a name or a face to the donor.

Such comments reflect what some participants in a study of assisted human reproduction have said about their experiences of donating ovarian eggs: that they wanted to know more about the recipients of their donation than the system allowed (Shaw, 2007). In Shaw's (2007) research the definition or expectation of altruism from donation did not necessarily accord with the experiences of those who donated, some of whom expressed wanting more information (see also Glover and Rousseau, 2007).

One participant referred to the importance of acknowledging reciprocity with the term 'pono na', and described this as meaning to present, or to address and balance what has been offered between two sides. Atareta Poananga (1998) 
discusses pono in relation to Maori dispute resolution, stating that pono is true and honest, a meaning associated with the concept 'tika', to be right and proper. If differences occurred between parties, the resolution required balance to be restored. Poananga notes, 'The principles of tika and pono would be part of the decision-making process. Utu (reciprocal payment) would be exacted in some form to re-assert the balance and bring rangimaarie or harmony to the community' (1998:116). In keeping with Poananga's observations, the interviewee has drawn upon the meaning of restoring the balance between parties in a community, and applied it to the giving and receiving of tissues in transplantation.

Another participant elaborated on the meaning of exchange between parties with reference to the concept utu, and the importance of reciprocity in relationships. The participant who used this term commented:

I think for some people, if it's a major organ and to receive a transplant someone has to die, I think it helps to know in terms of acknowledging whakapapa and utu as well. Now what I mean with utu is reciprocity rather than revenge, and to honour that person for what they've done, and that person's whakapapa.

As Ranginui Walker (1990:69) states, the concept 'utu' has a variety of dimensions. One expression of utu involves transgressions that disturb or harm social relations, requiring utu to restore the balance. Another form of utu is gift giving, which also recognises the importance of social relationships. Walker notes that, for Maori, social relationships and collective responsibility are emphasised through utu, and this could apply to individuals, whanau or to hapu. Metge (1995:100), too, notes that utu is a concept of reciprocal exchange, the principle being that 'anything received should be requited with an appropriate return'. Metge (1995:100-101) also notes rules around reciprocity, that oblige the recipient to give, not what has been received, but what could be incrementally more; that the return could be delayed months, years or generations later; that the return should be different in kind; and that the return does not have to be made to the giver, but could be made to the group that they belonged to or their descendants.

In interviews, discussion of this form of ongoing reciprocity beyond just the transplantation process was evident. Participants often referred to ongoing contributions after transplantation, or 'giving back' to others. 'Giving back' included a variety of areas: ongoing involvement with support organisations for people requiring or with transplants; supporting other recipients and their 
families with information or ongoing contact; talking to the wider community about organ donation; and raising awareness of organ donation in the Maori community. For example, two participants spoke of developing a project which explored the story of transplantation for their whanau, and involved going out to raise awareness of the issue amongst Maori. They noted:

In our project [she] wanted to give something back so, and we all support that $100 \%$, so we've done a project on our experience. It's just telling our story. That way nobody can fault anything, because it's our story. And like my thing was awareness, and I don't think her journey is ever going to stop. It didn't stop at the transplant, it just carries on, it continues. Because now there are a few experiences like she was saying the spiritual side of things where she can't find an answer for so that's the journey now, that's the project for her. It's a spiritual thing for me: it's awareness and promotion.

\section{WELLBEING}

As noted above, for some interview participants, but not all, their experiences of donation had spiritual significance, or were related to cultural wellbeing. Aspects of spirituality were referred to by nine participants. Several referred to spirituality in relation to experiences and transplantation, while many related spirituality to wellbeing and needs in the hospital setting. These elements were connected to perceptions of the body. As one participant noted, all parts of the body were equally important and thus carried commensurate symbolic weight. In their view:

The heart is just as important as the eye, just as important as the kidney, the liver, the lung. I don't think that there's any distinction or differentiation between any of the organ parts. To a Maori, even a clump of hair is still the whole thing. It's still got spiritual connections. As does a heart, as does a lung. So, no, I don't think there's any distinctions.

For this interviewee, the imprint of personality and spirit is contained in all matter derived from the body. As Lewis and Pickering (2003) point out, this means that taking a 'defunct' organ from one body and replacing it with a vital organ from another body is not a straightforward techno-medical event but has ramifications beyond the bodies of the individuals involved.

Lewis and Pickering (2003:34) also refer to the importance of the spiritual concept of tapu (sacred, prohibited, restricted) for Maori. Three participants 
related tapu to understandings of traditional cultural viewpoints. As an example, a participant commented that the traditional view is,

That we don't exchange anything like fingernails, hair, skin, and that nobody else must have access to those. Of course in pre-European times our people didn't know about heart or organ donation and that, but yeah as far as anything off your body was tapu and nobody else were to have access to those.

For wellbeing, several participants mentioned using karakia before and after transplantation. Roberts (2005:7) speaks to the importance of karakia (invocations or prayer) for Maori in relation to the transfer of genetic material, to ensure spiritual balance and safety, or to mitigate any adverse effects of the transfer. Participants in this research also appeared to use karakia in the hospital setting for organ transplantation for similar reasons. Some were offered support directly from staff, or were given the option of Maori support staff. One participant noted:

We were asked by the social worker, the Maori one, she came and supported us. But we were alright because we had our own support... We were offered kaumatua (an elder) and all the support in the world. And we can do our Maori stuff ourselves; we can do karakia and things like that-all those spiritual things.

Another recipient spoke of using karakia as part of the recovery process after the transplant. They, too, were offered cultural support, but chose to use whanau who helped with karakia. They commented:

There wasn't so much cultural significance in the hospital, as such, because it was offered and I didn't accept so I can't comment on it. And I wasn't overly religious or sensitive to that side until [I talked with] my cousin and her husband. I suppose you could sense it with me and he could sense that my wairua wasn't intact. And that I needed to get to my taha Maori and my wairua Maori, as it would speed my recovery. And once he started on his karakia, and then we just started talking and finished with his karakia, I felt really good. Well, my wairua felt good and that helped my tinana to get better and my recovery to get better. And ah, I think, I just think that has really helped me to avoid any rejection.

For this recipient, the experience of the operation led to the embracement of their taha Maori or cultural side, including wairua or spiritual beliefs, and the 
link to their tinana or body.

While many did feel they were supported as Maori by health care professionals (particularly the interviewees undergoing liver or heart transplantation), other participants felt the health system did not adequately cater for their needs as Maori. A kidney donor felt there was insufficient information for them about being a donor during the period when they donated, and that the information resources available had no Maori content as they were adapted from the Australian context. This caused them concern, and they commented:

I think for Maori in particular for transplantation is that, I think they deserve... in my experience I think that was what was carrying me through was that was my only hesitation. If anyone could guarantee me that my whole cultural wellbeing was going to remain intact, I don't think I would have had so much angst before. And I think that's a huge one. So I think there's still a lot to be done in addressing all those [issues].

After the operation, this participant spoke of the need to seek health care from a Maori health provider, where they used mirimiri, or Maori massage, for healing. They said:

And I was just trying to recover, with scars and wounds and things, and I was really struggling actually. And the only, the only lifesaver was that my sister... I think she kind of recognised some concerning signs really, and then they put me off to a Maori provider, health provider they got, they offered mirimiri. And I knew the woman that did that actually and that's you know I needed to go somewhere to sort of feel, I don't know how to describe it; it was a real sense of healing... But it wasn't so much, it wasn't just the physical part of the massage, because what the mirimiri was doing or the massaging, was actually allowing you to sort of express a whole lot of emotion, kind of poured out on the table.

As stated above, attending to the physical, spiritual and feeling sides of Maori wellbeing is in keeping with a holistic understanding of health symbolised by the whare tapa wha model.

VIEWS ON DONATION AND IDENTITY

Participants also reflected upon how Maori and organ donation was portrayed 
or understood more widely in the community. One participant, a kidney donor, noted frustration with the views expressed by commentators in the media that Maori did not donate. For this participant, those views did not adequately reflect their experience as a kidney donor, and they referred to a multiplicity of Maori understandings on the issue. Remarking on the idea of a Maori view on organ donation and transplantation, this interviewee said:

I wouldn't know that [there was a Maori perspective] from my own immediate family. You kind of get told that there is, you hear it in the media. Certain people would tell you that this is the Maori way of thinking, and I don't really think like that. But you get that with a lot of things, don't you? People tell you what the Maori way of thinking is: as if it is one way of thinking. It makes more sense to me that if someone you love needs help then you'd help them if you could. And I think if you do it with care and respect then that's what matters. That's why I think that whole thing about looking after live donors is actually quite important.

Another kidney donor expressed a similar view, stating:

Well I'm assuming that the traditional Maori view out there is that it's a no-go zone, and my response is I think it's a personal choice, because of our positive [experience]. And actually even if it hadn't been a success, I think I would still. I'd never because, you know, this meant for us you should do it. I think our role is about facilitating evidence and sharing experience to say this is what was possible for us. Yeah but I don't know, there is a real danger of people assuming what the Maori view is, because I think we're all individuals too, and I think you'll find everybody has their own personal view on it.

This complexity of Maori identity is noted by McIntosh (2007). In contrast to the idea of a fixed traditional identity as essentially defining Maori, McIntosh observes what she calls 'fluid Maori identity' as people adapt to new social situations and conditions, as well as recognising forced forms of identity that are socially constructed in a manner beyond the control of the marginalised individual. The fluidity to which McIntosh refers appears in the comments of some participants' views of their identity as Maori, and the questioning of what is considered to be the Maori view of donation.

Several interviewees sought guidance from kaumatua (elders) to inform themselves on the issue of donation. A whanau member of a recipient observed that 
views on donation had changed as tikanga changed. This interviewee said:

If it's going to save more Maori then I'm for it. I know that there are a lot of debates and there's a lot of tikanga around going to the grave whole and things like that. And I've had really good discussions with a couple of kaumatua that I work with and the one thing that keeps coming back to me is that tikanga is changeable and it needs to be adapted. And in this instance I think that we as Maori need to be a little bit wider thinking and to be a little bit, what's the word I want, to be a little bit embracing about organ transplant as a whole really.

This interviewee's comments synch up with Durie's (2008) observation that tikanga and Maori custom come under scrutiny when whanau wellbeing is involved. On this point Durie suggests that:

assisted reproductive technologies and organ transplants are sometimes seen as antithetical to Maori custom because they offend the 'principles of nature'. However, when the ethical focus shifts from attention to cellular details to the wider question of human survival, the debate takes on new dimensions (2008:11).

Another participant spoke of how the experience of donation had changed the ways their whanau viewed donation. Reflecting on this issue, they remarked:

So we've come to learn that if organ donation affects you in some way, if you know someone then you're going to take it on board and learn more. If you have no problems and have no connections with donating organs or tissues or anything like that then you probably would be a 'no'. Because that's how I was when I was young; there's no way I am going to give my tissue away, but then you meet people and things like that become involved in your life and your mind just changes as you get older. You see a lot more things. So that family has gone from 'no way' to 'yes', I would.

The comments of this interviewee illustrate that attitudes or perception of donation can change within families over time. Importantly, the direct experience of organ donation shaped the ongoing perspectives for this whanau as a whole.

The ongoing dynamism of Maori culture and developments in response to new issues and material change has been identified by Mead (2003). The challenges of applying Maori beliefs to new situations can be viewed in issues such as ge- 
netic modification and organ transplantation. For example, in Roberts' (2005) study of Maori views of genetically modified organisms she notes an increasing clash of world views and culture. Roberts' opinion is that 'in embracing and affirming the importance of traditional values, generations of [...] Maori also need to accept the challenge of applying them to present and future issues' (2005:9). In this respect, she says the application of traditional values to the present can be seen as 'walking backwards into the future.' Participants in the foregoing study, as evidenced by the comments presented in this article, also express the importance of applying Maori world views to experiences of organ donation and transplantation. In explaining their experiences, the interviewees demonstrated a dynamism and diversity in beliefs. For them, as for Roberts in the exploration of genetic modification, participants expressed culturally informed perspectives on ongoing and developing medical processes.

\section{CONCLUSION}

This study of experiences of transplantation and donation explored a range of themes that drew upon understandings of whanau, whakapapa and identity. A holistic view of embodiment was conveyed in the interviews, encapsulating understandings of the body beyond individualistic notions of identity separate from community and world. These conceptions included te whare tapa wha, with integrated elements of tinana, wairua, whanau and hinengaro. The importance of whakapapa in donation was illustrated in ideas around transplantation within whanau, and between non-related people, indicating important and different distinctions between live and deceased donation. Like data from other recent studies on experiences of organ donation and transplantation, Maori meanings attributed to the term 'gift' by participants in the present study were also varied. The views of the gift ranged from altruistic understandings that donation was given and accepted freely with no conditions, to distinctive conceptions related to reciprocity and exchange. Terms such as taonga conveyed the importance participants gave to receiving an organ, and concepts such as utu reflected specific cultural meanings in addressing reciprocity. Difficulty in being able to reciprocate under the current anonymous donor system was mentioned, illustrating that the donation system does not always accord with the expectations, beliefs and values of those affected by it.

Spirituality and wellbeing was discussed, and while not all participants agreed with the significance of this aspect for their experience, many acknowledged this phenomenon as important in the transplantation process. Cultural beliefs informed the experiences of many participants, in direct contrast to the perception that Maori do not donate because of cultural reasons. The popular 
belief that there is a monolithic and fixed Maori view on organ donation is not confirmed by the findings of the foregoing study. The fact that some participants sought to understand and be informed about tissue donation through conversations with whanau or kaumatua, in keeping with the findings of Roberts' research into genetic transplantation, demonstrates that the process of applying Maori knowledge to organ or tissue transplantation is an ongoing task.

\section{NOTES}

1 This study is part of a larger research project investigating New Zealanders' experiences of organ donation and transplantation. The study was funded by the Marsden Fund. The project has been granted ethics approval (MEC/O8/03/027 and AUTEC 08/179).

2 Several whanau members identified their ethnicity as non-Maori. Their comments are analysed as part of the larger research project, and not in this article.

\section{REFERENCES}

Durie, M. 1985 'A Maori Perspective of Health', Social Science \& Medicine, 2O(5): $483-486$.

Durie, M. 2008 Bioethics in Research: the Ethics of Indigeneity. Paper presented at the Ninth Global Forum on Bioethics in Research. Retrieved from http://gfbry. hrc.govt.nz/articles/The Ethics of Indigeneity FULL article.pdf

Glover, M. 2008 Maori Attitudes to Assisted Human Reproduction: An Exploratory Study, Auckland: University of Auckland, Department of Social and Community Health.

Glover, M. and Rousseau, B. 2007 “"Your Child Is Your Whakapapa”: Maori Considerations of Assisted Human Reproduction and Relatedness', Sites: A Journal of Social Anthropology and Cultural Studies, 4(2):117-136.

Haddow, G. 2005 'The phenomenology of death, embodiment and organ transplantation', Sociology of Health \& Illness, 27(1): 92-113.

Healy, K. 2006 Last Best Gifts: Altruism and the Market for Human Blood and Organs. Chicago and London: The University of Chicago Press.

Henare, A. 2007 'Taonga Māori: Encompassing rights and property in New Zea- 
land', in A. Henare, M. Holbraad, and S. Wastell (eds) Thinking Through Things: Theorising Artefacts Ethnographically. London: Routledge: 47-67.

Lewis, G., and Pickering, N. 2003 'Maori Spiritual Beliefs and Attitudes Towards Organ Donation', New Zealand Bioethics Journal, 4(1):31-35.

Mauri Ora Associates 2009 Maori Pacific Attitudes Towards Transplantation: Professional Perspectives. Retrieved from http://www.moh.govt.nz/moh.nsf/ pagesmh/930o/\$File/maori-pacific-attitudes-towards-transplantation.pdf

McIntosh, T. 2007 'Power, Powerlessness and Identity', in: B. Curtis, S. Matthewman and T. McIntosh (eds.) TASA \& SAANZ Joint Conference: Public Sociologies and Trans-Tasman Comparisons. Auckland: Department of Sociology, University of Auckland.

Mead, H.M. 2003 Tikanga Maori: Living by Maori Values. Wellington: Huia.

Metge, J. 1995 New Growth from Old: The Whanau in the Modern World. Wellington: Victoria University Press.

Ministry of Health 2004 Review of the Regulation of Human Tissue and Tissuebased Therapies: Submissions Summary. Wellington: Ministry of Health.

Ngahooro, J. 2010 'Farewelling Body Parts “Would Help Maori Donors”. Dominion Post [Online]. Retrieved from http://www.stuff.co.nz/national/politics/3563310/Farewelling-body-parts-would-help-Maori-donors [Accessed 23 May 2010].

Poananga, A. 1998 'Towards a Ngati Porou Justice System', in Maori and the Criminal Justice System, He Whaipanga Hou Ten Years On, 1988-1998. Wellington: Nga Kaiwhakamarama I Nga Ture.

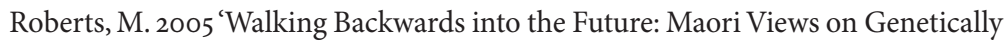
Modified Organisms', World Indigenous Nations Higher Education Consortium Journal. Retrieved from http://www.win-hec.org/docs/pdfs/Journal/ Mere Roberts.pdf

Roberts, M. and Fairweather J.R. 2004 'South Island Maori Perceptions of Biotechnology', Research Report No. 268. Agribusiness and Economics Research Unit. 
Roberts, M., Haami, B., Benton, R., Satterfield, T., Finucane, M., and Henare M. 2004 'Whakapapa as a Maori Mental Construct: Some Implications for the Debate over Genetic Modification of Organisms', The Contemporary Pacific, 16(1):1-28.

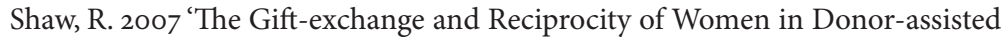
Conception', The Sociological Review, 55(2):293-310.

Shaw, R. 2008 'The Notion of the Gift in the Donation of Body Tissues', Sociological Research Online, 13(6). Retrieved from http://www.socresonline.org. $\mathrm{uk} / 13 / 6 / 4 \cdot \mathrm{html}$

Shaw, R. 2010a 'Perceptions of the Gift Relationship: Views of Intensivists and Donor and Recipient Coordinators', Social Science \& Medicine, 70 (4):609-615.

Shaw, R. 2010b 'Organ donation in Aotearoa/New Zealand: Cultural phenomenology and moral humility', Body \& Society, 16(3):127-147.

Te Puni Kokiri. 1999a Hauora o te Tinana me ona Tikanga: a Guide for the Removal, Retention, Return and Disposal of Maori body Parts and Organ Donation: Maori and their Whanau. Wellington: Ministry of Maori Development.

Te Puni Kokiri. 1999b Hauora o te Tinana me ona Tikanga: a Guide for the Removal, Retention, Return and Disposal of Maori body Parts and Organ Donation: Service providers. Wellington: Ministry of Maori Development.

Te Rito, J. 2007 'Whakapapa: A Framework for Understanding Identity', MAI Review, (2):1-10. Retrieved from http://www.review.mai.ac.nz/index.php/MR/ article/view/56/55

Tutton, R. 2004 'Person, property and gift: Exploring languages of tissue donation to biomedical research', in R. Tutton and O. Corrigan (eds) Genetic databases: Socio-ethical issues in the collection and use of DNA. London: Routledge: 19-38.

Waldby, C. and Mitchell, R. 2006 Tissue Economies: Blood, organs and cell lines in late capitalism. Durham, NC: Duke University Press.

Walker, R.J.199o Ka Whawhai Tonu Matou: Struggle Without End. Auckland: Penguin. 